\title{
RAPORTUL DINTRE INTELIGENŢA EMOŢIONALĂ ŞI FACTORII DE PERSONALITATE A PREADOLESCENȚILOR
}

\section{THE RELATIONSHIP BETWEEN EMOTIONAL INTELLIGENCE AND THE FACTORS OF PERSONALITY OF PREADOLESCENTS}

Lorena Maxim, Doctorand în psihologie, Bacău, România

\section{CZU: 159.922.7:159.942}

\section{Rezumat}

Acest articol sintetizează și prezintă informații despre interrelația dintre inteligența emoțională și personalitate la preadolescenți. Studiul privind această relaţie mutuală, este realizat pentru a alerta cu privire la conştientizarea importanţei dezvoltării inteligenţei emoţionale la vârsta preadolescentă în dependenţă de situaţia socială de dezvoltare, înţelegerea funcţionării şi adaptării eficiente a preadolescenţilor în obţinerea performanţelor comportamentale raportate la realitatea socială distinctă.

Cuvinte cheie: inteligenţă emoţională, personalitate, preadolescenţi, interrelaţie, familie, mediu social.

\section{Abstract}

This article summarizes and presents information aboutthe interrelationship between emotional intelligence and personality in preadolescents. The study on this mutual relationship is conducted to raise the alarm about the importance of developing emotional intelligence in preadolescence depending on the social developmental situation, understanding the functioning and effective adaptation of preadolescents in obtaining behavioral performance related to distinct social reality.

Key words: emotional intelligence, personality, preadolescents, interrelationship, family, social media.

Analiza interrelaţiei dintre factorii de personalitate și inteligenţa emoţională la preadolescenţi, a factorilor determinanţi, a însuşirilor de personalitate ale preadolescentului în dependenţă de situaţia socială de dezvoltare, este foarte importantă, atât pentru stabilirea esenţei acestui fenomen, cât şi pentru înţelegerea ulterioară a particularităţilor de dezvoltare a inteligenţei emoţionale, precum şi a personalităţii preadolescentului. Ţinând seama de complexitatea şi specificitatea trăirilor acestei vârste, pentru a preveni neliniştile confuze specifice acestei perioade, uneori declanşatoare ale unor traume ce s-ar putea prelungi în maturitate, necesitatea dezvoltării inteligenţei emoţionale este indiscutabilă pentru această generaţie grăbită, care uneori îşi trăieşte sentimentele cu violenţa soluţiilor imediate şi totale, ce izvorăşte din însăşi caracteristicile acestei vârste.

Între cele două există o strânsă legătură. Personalitatea este ghidată de reacţiile emoţionale pe care oamenii le resimt într-o situaţie dată. EQ apare ca o funcţie activă a personalităţii, ca o expresie de constituire progresivă a acesteia, evoluând în măsura în care se dezvoltă personalitatea, în strânsă dependenţă cu componentele care o constituie.

Formarea personalităţii este un proces continuu, cu perioade de stagnare relativă, momente de criză sau chiar regres, diferite în funcţie de particularităţile individuale şi de vârstă ale subiecţilor. Personalitatea este cea care determină nivelul normal al stării de fericire, atât de diferită de la un 
individ la altul şi care tinde să revină la nivelul iniţial imediat ce ne-am adaptat unei situaţii de succes sau de eşec [4, p. 118].

Filozofi ca Gautama Buddha şi Lao-Tsu (din Asia Antică), precum şi Epicur, Epictet şi Marc Aureliu (din Grecia şi Roma Antică), au confirmat că: "oamenii sunt constructivişti, ei nu devin pur şi simplu tulburaţi din cauza unor influenţe externe, ci contribuie şi ei înşişi într-un mod semnificativ la această situaţie, precum şi în menţinerea gândirii, a sentimentelor şi a acţiunilor lor disfuncţionale. Epictet a pus bine probleme acum două mii de ani „Oamenii nu sunt afectaţi de ceea ce li se întâmplă, ci de cum înţeleg ei ceea ce li se întâmplă” [11, p. 20].

Personalitatea este o formaţiune activă, energică, care se interpretează şi se cunoaşte mai bine „,raportată la realitatea socială distinctă“. În procesul transformării personalităţii există câteva perioade sau împrejurări esenţiale, care lasă urme asupra evoluţiei individului. Acum, se cristalizează idealurile ca modele universalizate de acţiune şi se pregătesc premisele unei bune integrări, conform cerinţelor mediului social dat [14, p.176].

În preadolescenţă începe să se contureze idealul de viaţă. Se petrec o serie de schimbări caracteristice la nivelul personalităţii. Etapa autonomiei morale este în debut, atitudinile şi comportamentele fiind orientate de certitudini morale şi nu de simple imperative interiorizate sub influenţa cerinţelor parentale. Preadolescenţii nu mai aderă la criteriile morale ale familiei ci trec totul prin prisma gândirii şi experienţei lor. Dezvoltarea conştiinţei de sine şi a cunoaşterii de sine se intensifică în mod deosebit în acest stadiu. „Eul social este în centrul atenţiei preadolescentului. Ei devin interesaţi de identificarea însuşirilor lor şi de originalitatea propriei personalităţi" [7, pp. 289, 291, 292].

În această schemă a personalităţii are loc traversarea de la caracteristice specifice copilăriei la o nouă personalitate, conturată mult mai clar cu privire la propria identitate, la echilibru între aspiraţie şi posibilităţi, la creşterea experienţei personale de viaţă şi la observarea vieţii altora, formându-se trăsături însemnate ale personalităţii inventive, cum ar fi: încredere în forţele proprii spirit de imparţialitate, asumarea riscului, înţelegerea temeinică a valorilor, comparaţia cu alţii, etc. Această etapă reprezintă ,şi stadiul în care se formează câteva componente ale personalităţii care exprimă funcţia proiectivă şi pe cea orientativă a acestuia. Cele mai importante sunt: structurarea sistemului propriu de valori, cristalizarea unei concepţii personale asupra vieţii proprii şi a vieţii în general, apariţia conştiinţei apartenenţei la generaţie, idealul de viaţă, imaginea de sine şi identitatea de sine, eul fizic, eul spiritual, eul social”. 
Journal of Psychology. Special Pedagogy. Social Work (PSPSW) e-ISSN: 1857-4432, p-ISSN: 1857-0224, Volume 62, Issue 1, 2021, DOI 10.46728( http://psihologie.upsc.md) Psychology and Special Education Faculty “Ion Creangă” State Pedagogical University from Chișinău

În preadolescenţă se înregistrează schimbări importante în structura personalităţii constând, atât în stabilizarea unor componente, de exemplu aptitudinile, cât şi în reorganizarea altora, respectiv caracterul sau idealul de viaţă. În această perioadă apar schimbări noi din subansamblu de orientare al personalităţii: modelul individual de valori, viziunea despre propria viaţă şi a celorlalţi. De asemenea, se produc modificări şi în structura imaginii de sine şi a identităţii de sine. În concluzie, personalitatea este insuficient consolidată în această perioadă.

În ceea ce priveşte caracterul în preadolescenţă se produc schimbări foarte importante. Unele însuşiri caracteriale apărute în copilărie se consolidează, dar cele care sunt legate de relaţiile cu persoanele adulte şi cu instituţiile sociale intră într-un proces de mari transformări, care nu este lipsit de încordare, contradicţii, neînţelegeri şi numit de cercetători „,criza de originalitate”.

Prin urmare, în această etapă, se desfăşoară o acţiune intensă şi amplă de schimbare, dezvoltare şi reorganizare a personalităţii care are o importanţă deosebită pentru următorul ciclu al vieţii, cel de maturizare. Pe fondul acestor însuşiri generale la care ne-am referit, personalitatea poate prezenta foarte multe particularităţi individuale.În general, în preadolescenţă se accentuează caracterul particularizat şi individualizat al dezvoltării psihice. Aflându-se într-un ,proces de transformare, personalitatea preadolescentului prezintă o anume fragilitate", ce necesită sprijin important din partea familiei, a instituţiilor educative şi a societăţii, în general [8, pp. 45, 46, 47, 48, $51,52]$.

Personalitatea se conturează, se particularizează în această etapă existând o corespondenţă între ea şi stadiul dezvoltării inteligenţei emoţionale, chiar dacă reperele cronologice corespunzătoare stadiilor au anumite variabilităţi în funcţie de condiţiile și solicitările mediului social. Preadolescentul îşi intensifică personalitatea prin atenţia crescută faţă de revelarea propriei persoane, prin comportamentul său inconsecvent, prin aspiraţia de a se diferenţia de cei din jurul său. După cum se ştie, oamenii diferă foarte mult între ei. Percepţia oricărei trăiri depinde de structura de personalitate. În general, reacţiile diferă semnificativ de la individ la individ, în funcţie de tipul de personalitate.

Personalitatea este unitatea bio - psiho - socială, structurată în procesul adaptării la mediu. $\mathrm{Nu}$ trebuie pierdut din vedere faptul că modul de a acţiona al omului este determinat, în mare măsură, de dispoziţiile, simţămintele şi trăirile emoţionale pe care le încearcă la momentul dat şi pe care i le trezesc situaţiile interacţiunilor sociale [12, p.667].

Tendinţele biologice, condiţiile de mediu şi sociale au o contribuţie majoră cu privire la controlul emoţional în situaţiile dificile, inconfortabile. Ei nu au avut oportunitatea de a învăţa de a 
exersa unele abilităţi interpersonale, de a-şi asuma responsabilitatea pentru reacţiile lor. Dezvoltarea EQ, îi va ajuta să conştientizeze că deşi se află într-o astfel de situaţie, sunt capabili să facă faţă situaţiei. Din cauza convingerilor disfuncţionale, se declanşează tensiuni, suferinţe nesănătoase, interferenţe ce împiedică obţinerea de rezultate sociale şi individuale bune. Dificultăţile emoţionale şi de comportament sunt create de convingeri ilogice, inconsistente, care nu sunt conforme cu realitatea. O gândire realistă, pragmatică şi logică, va evita supoziţiile prestabilite şi majoritatea dificultăţilor emoţionale şi de comportament, vor fi supuse schimbării în vederea dezvoltării abilităţilor sociale şi îmbunătăţirii sănătăţii emoţionale.

„Asocierile implicite ale trăsăturilor de personalitate urmează axele succes-eşec în plan personal şi al relaţiilor sociale, repectiv succes-eşec în plan professional” [6, p.229].

După Gordon Allport, personalitatea umană este ,organizare dinamică în cadrul individului a acelor sisteme psiho-fizice care determină gândirea şi comportamentul său caracteristic” [3, p.75].

Freud susţine că ,,personalitatea este constituită din trei structuri importante, id (şinele), ego (eul) şi superego (supraeul). Fiecare parte a personalităţii are propria sa funcţie, iar în personalitatea sănătoasă, matură, cele trei părţi produc un comportament echilibrat, bine integrat”" [5, p.117].

Personalitatea este o structură compusă ce cuprinde o serie de ,trăsături şi calităţi formale, dinamico energetice (temperamentul), de conţinut, socio-morale şi axiologice (caracterul) şi aspecte instrumentale, performanţiale" $[9$, p.77,79]. Este întreaga organizare mentală a fiinţei umane în orice stadiu al dezvoltării sale. Ea imbrăţişează fiecare aspect al caracterului uman: intelect, temperament, abilitate, moralitate şi fiecare atitudine care s- a format în cursul vieţii cuiva [3, p.16].

Orice proces emoţional activ, care se desfăşoară într-o situaţie sau alta, are un caracter integrat, de sistem. Aceasta se exprimă, pe de o parte, în faptul că el angajează personalitatea ca tot, iar pe de altă parte, în complexitatea structurii sau arhitecturii sale interne. Valoarea intensităţii este condiţionată şi de structura de personalitate, de experienţa de viaţă şi afectivă anterioară. Aceasta face ca, în faţa uneia şi aceleiaşi situaţii, diferiţi subiecţi să răspundă emoţional cu trăiri de intensităţi diferite [12, p. 644, 653].

Deşi personalitatea umană are câteva elemente înnăscute şi relativ fixe importante, ea se dezvoltă de asemenea în mare parte, din influenţe relaţionale şi sociale. Oamenii sunt puternic influenţaţi sau condiţionaţi de creşterea lor într - un anumit mediu cultural [11, p.28]. Personalitatea se formează în decursul vieţii numai în cadrul relaţiilor sociale, prin interacţiunea individului cu multitudinea şi varietatea relaţiilor sociale. Esenţa personalităţii umane o reprezintă ansamblul relaţiilor sociale in expresia lor subiectivă, interiorizată. Calitatea personalităţii va depinde de 
calitatea relaţiilor sociale (mediului social) în care ea se formează, imperfecţiunile şi slăbiciunile mediului social, ducând la înstrăinarea sau destructurarea personalitătii [16, p.30]. „Toate drumurile individului uman sunt legate de familie" [13, p.126]. Dintre toți factorii determinanți ai personalității, familia este cea mai importantă. Familia reprezintă punctul de plecare al formării ca şi personalitate. Toate formele de manifestare a unui individ în societate sunt modele preluate din familie.

Mediul în care cresc, se dezvoltă și relaţionează puberii, influenţele acestuia ,reprezintă o irezistibilă forţă pedagogică. Familia este cea mai indicată să dezvolte sentimentul de comuniune socială. Dimensiunile sentimentului de comuniune socială vor apărea în toate manifestările omului. Familia prezintă avantaje incontestabile şi cu greu se poate recomanda o instituţie în care copiii să fie mai bine crescuţi decât în familie sub raportul conduitei judicioase"[1, pp 174, 175, 261, 263].

Atmosfera din familie este relevantă în procesul de dezvoltare atât al inteligenţei emoţionale cât şi al personalității preadolescenților educați în diferite medii sociale de viață (SSD). Lipsa iubirii, a afecţiunii, a încrederii, a înţelegerii, a securităţii, va avea influenţe negative asupra modificărilor care au loc în această perioadă de vârstă în plan biofizic, intelectual, social, afectiv, moral. Atât factorii sociali cât și familiali, reprezintă un risc de instabilitate emoțională şi un control emoţional redus.

Fiecare mişcare îşi are originea în personalitatea totală şi poartă în ea stilul de viaţă, fiecare modalitate de expresie se extrage din omogenitatea personalităţii, în care nu există nici contradicţie, nici ambivalenţă, nici psihic dublu. Toate rătăcirile emoţionale, toate trăsăturile de caracter infecte, manifestate în familie, la şcoală, în viaţă, în relaţiile cu ceilalţi, îşi arată provenienţa în deficitul de inteligenţă emoţională [2, pp.50, 157].

Abaterile comportamentului familial atrag sancţiunea socială şi favorizează perturbări sociale în sens mai larg[13, p.127]. „O persoană care trăieşte într-un mediu de iubire şi ocrotire, dezvoltă o personalitate fericită, optimistă, o alta care trăieşte într-un mediu deprivat unde este tratată nesatisfăcător dezvoltă o personalitate nesociabilă’'[5, p.122]. Altfel spus, familia constituie partea cea mai importantă a lumii interioare şi exterioare a unei persoane, indiferent de etapa de dezvoltarea a acesteia.

După C.G Jung (1995) rolul familiei în formarea personalităţii preadolescentului este esenţial. Problemele din viaţa părinţilor, atmosfera din familie, metodele de educare au o mare influenţă asupra stării lui psihologice, dezvoltării sistemului nervos, deoarece sânt aproape mereu „iniţiatorii direcţi ai nevrozei copilului sau componenţii principali ai acesteia” [15, p.76]. 
Journal of Psychology. Special Pedagogy. Social Work (PSPSW) e-ISSN: 1857-4432, p-ISSN: 1857-0224, Volume 62, Issue 1, 2021, DOI 10.46728( http://psihologie.upsc.md) Psychology and Special Education Faculty “Ion Creangă” State Pedagogical University from Chișinău

R. B. Cattell caracterizează personalitatea prin consistenţa trăsăturilor, ca pe ceva care permite o previziune asupra modului de a se comporta a individului într-o anumită situaţie: „personalitatea este ceea ce putem anticipa despre individ că va face într-o situaţie dată" [17, p.67].

Personalitatea este întreaga organizare mentală a fiinţei umane în orice stadiu al dezvoltării sale. Ea imbrăţişează fiecare aspect al caracterului uman: intelect, temperament, abilitate, moralitate şi fiecare atitudine care $\mathrm{s}$ - a format în cursul vieţii cuiva. A fost abordată cel mai des în termeni de trăsături. O trăsătură de personalitate este o caracteristică unică a unui individ. Psihologii au constatat că aceste trăsături pot fi grupate în cinci dimensiuni de bază, majore care descriu personalitatea unui individ, indiferent de cultura de apartenență a acestora (Modelul „Big Five” al personalităţii). Fiecare individ poate fi descris după cel puțin una dintre ele. Acestea sunt: extraversiunea, agreabilitatea, conștiinciozitatea, stabilitatea emoțională și deschiderea la nou.

În zilele noastre, Modelul Celor Cinci Factori (Five Factor Model/Big Five) reprezintă principala abordare şi perspectivă din care se măsoară personalitatea. Modelul Big Five, este compus din următorii factori:

1. Extraversia - arată capacitatea de orientare a capacităţii către exterior, modul de implicare în acţiune, sociabilitatea persoanei, optimismul.

2. Agreabilitatea - prinde în el diferenţele individuale relevante de interacţiunea socială (prietenie, plăcere) şi se referă îndeosebi la calităţile emoţionale ale persoanei si la comportamentele ei prosociale (amabilitate, generozitate, capacitate de înţelegere).

3. Conştiinciozitatea - vizează modul concret, caracteristic a individului de a trata sarcinile, activităţile, problemele care apar în viaţa lui.Cuprinde trăsături cum ar fi: ordinea, disciplina, responsabilitatea socială.

4. Stabilitatea emoţională - este perceput ca reţinând diferenţele individuale referitoare la caracteristicile emoţionale ale unei persoane (calm, mulţumit, emotiv, neemotiv), dar şi la diferitele dificultăţi emoţionale ale oamenilor (anxietate, depresie, iritabilitate, tensiune, încordare, etc).

5. Cultura sau intelectul - arată diferitele aspecte ale funcţiilor intelectuale (creativitate, inventivitate, deschiderea la experienţă, etc.) [19, pp. 242, 243].

Big Five reprezintă un compromis între poziţiile extreme pe care se situează Cattell şi Eysenck şi face trecerea de la studiul analitic la studiul sintetic al personalităţii, pornind de la expunerea şi analiza personalităţii în termeni numeroşi şi variaţi, la redarea şi analiza ei în termini mai puţin numeroşi şi relativ înrudiţi între ei [17 p. 70]. 
Inteligenţa emoțională ne ajută să facem explicabil comportamentul nostru şi al semenilor noștri. EQ nu este un dar al sorţii, ci o combinaţie de abilităţi individuale care pot fi învăţate. EQ este atât o competență, cât și o expresie a trăsăturilor de bază ale personalității. Acoperă toate domniile necesare procesării informaţiilor inter şi intra - personale. Utilizarea EQ poate fi perfecţionată continuu şi deschide avantaje valoroase pentru preadolescenţi.

Un nivel scăzut al inteligenţei emoţionale, stă la baza multor dificultăţi psihologice, având un impact negativ asupra dezvoltării armonioase a preadolescenţilor. Insuficienţa înţelegerii de sine, a nevoii de împlinire, poate conduce preadolescentul la revoltă împotriva sa şi a altora. Emoţiile negative deteriorează atât propria persoană, cât şi pe ceilalţi din jur. Înclinaţia spre o atitudine negativă slăbeşte latura emoţională, în cele din urmă subminînd personalitatea în ansamblu. [18 p. 59].

Adaptarea individului la mediu, controlul emoţional, se realizează prin intermediul inteligenţei emoţionale care implică componente de ordin afectiv, personal şi social, considerate ca fiind esenţiale pentru succesul individual.

De aceea, este necesar ca preadolescenţii să fie sprijiniţi să-şi depăşească manifestările, să-şi impulsioneze maturizarea emoţională, să fie ajutaţi în procesul dezvoltării inteligenţei emoţionale, proces echivalent cu maturizarea sa psihologică.,,Prin urmare, preadolescenţa înseamnă amplificarea structurii personalităţii şi accentuarea aspectelor diferenţiale ale manifestărilor ei" [7, p.294]. „Primul pas esenţial în dezvoltarea inteligenţei emoţionale constă în conştientizarea propriei personalităţi” [10 p. 89]. „Realitatea este că noi ne alegem întotdeauna emoţiile. Simpla conştientizare a acestui lucru ne poate conferi foarte multă putere. Noi suntem autorii propriilor noastre experienţe emoţionale" [14, p.348].

O inteligenţă emoțională dezvoltată, îl poate ajuta pe preadolescent în căutarea şi adoptarea unei conduite care să contribuie în situaţii diverse, la conturarea personalităţii sale.

Pentru a deveni o personalitate sociabilă, neprefăcută, capabilă de a perpetua relaţii naturale, normale, cu o varietate de oameni, pentru a ne comporta într-un mod inteligent din punct de vedere emoţional şi a avea control asupra reacţiilor noastre emoţionale, este necesară intervenţia mediatoare şi modelatoare a inteligenţei emoţionale şi dezvoltarea acesteia. Astfel, fiecare zi va veni cu experienţe noi, iar preadolescenţii vor şti cum să reacţioneze în plan emoţional, evoluând şi cultivând emoţiile pozitive în funcţie de deciziile luate.

O inteligenţă emoţională dezvoltată facilitează selectarea circumstanţelor şi mijloacelor de atingere a scopurilor propuse. Este clar că inteligenţa emoţională deschide perspective de reuşită în 
orice situaţie a vieții, iar în acest context considerăm actuală și oportună investigarea inteligenței emoționale, în special a interrelației dintre inteligența emoțională și personalitate la preadolescenți.

\section{BIBLIOGRAFIE}

1. ADLER, A. Cunoaşterea omului. tr. de L. Gavriliu. Bucureşti: IRI, 1996.

2. ADLER, A. Sensul vieţii. Editura IRI, București, 1995.

3. ALLPORT, G. Structura şi dezvoltarea personalităţii. tr. de I. Herseni. Bucureşti: Didactică şi Pedagogică, 1991.

4. ANDRE, C., LELORD F. Cum să ne exprimăm emoţiile şi sentimentele. tr. de M. Georgescu. Bucureşti: TREI, 2003.

5. BIRCH, A. Psihologia dezvoltării. tr. de L. Băiceanu. Bucureşti: Tehnica, 2000.

6. CHELCEA, S., DUDUCIUC A., IVAN L. Psihologie socialã. Studiul interacţiunilor umane, Bucureşti: Comunicare.ro, 2013.

7. CREŢU,T. Psihologia vârstelor, București: Credis, 2011.

8. CREŢU, T. Psihologia adolescentului şi adultului. Ministerul Educaţiei şi Cercetării. Proiectul pentru învăţământul rural, 2005.

9. COSMOVICI, A., IACOB L. Psihologie şcolară. Iaşi: Polirom, 1998.

10. CRAUGHWELL, T. Testează-ți inteligența emoțională: București: Litera, 2016.

11. ELLIS A., MACLAREN C. Terapia raţional emotivă şi comportamentală, tr. Urian L., Bucureşti, Editura All, 2018.

12. GOLU, M. Fundamentele psihologiei. București: Fundaţia România de Mâine, 2007.

13. MITROFAN I., MITROFAN N. Elemente de psihologie a cuplului. București: Şansa SRL, 1994.

14. NELSON, B. Codul emoțiilor, tr. Hanu C., Brașov: Adevărul Divin, 2012.

15. NICOLA, I. Tratat de pedagogie școlară. București: Aramis, 2000.

16. PALICIA, M. Prelegeri de psihopedagogie, Timişoara: Orizonturi universitare, 2002.

17. ȚUȚU, M. Psihologia personalitaţii, Bucureşti, Editura Fundaţiei România de Mâine, 2005.

18. WOOD, R., TOLLEY H. Inteligenţa emoţională prin teste. București: Meteor Press, 2003.

19. ZLATE, M. Eul şi personalitatea. București: Trei, 2008. 